Public health

\section{Rabies: old disease, new challenges}

$\infty \quad$ See related articles pages 557,564 and 567

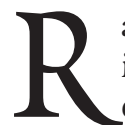

abies is a disease entrenched in history, dating back to ancient Egypt. Caused by an RNA virus belonging to the Lyssavirus genus, rabies is capable of infecting all mammals.

The World Health Organization marked Sept. 8, 2007, as World Rabies Day, to bring attention to the unacceptably high mortality: 50000 people die each year from the disease, ${ }^{1}$ with India carrying the greatest burden of more than 20000 deaths annually (see page 564). The remainder occur in Southeast Asia (particularly the Philippines), Oceania, Africa and Latin America. ${ }^{1}$

Although rates of human rabies in North America have declined substantially, in large part because of dramatic decreases in rabies among dogs and cats, a concerning trend is the increasing rate of rabies among wildlife (raccoons, skunks, foxes and bats). Urban expansion has brought wildlife in greater proximity to humans. Since $1980,58 \%$ of human cases in the United States have been due to bat bites. ${ }^{2}$ In Canada, between 2000 and 2005 , a total of 2238 cases of confirmed animal rabies were reported (about 373 per year). ${ }^{3}$ Skunks accounted for $40 \%$ of the cases, bats for $26 \%$, foxes for $\mathrm{II} \%$ and raccoons for $8 \%$. The human burden of rabies has resulted in 23 deaths in Canada since I924, all of which occurred in 6 provinces: Quebec (I2), Ontario (6), Saskatchewan (2), and British Columbia, Alberta and Nova Scotia (I each). Since I 985 , only 2 deaths have been reported, both from bat exposure.

Rabies is transmitted to humans through exposure to saliva from infected animals (from bites, scratches, or licks on broken skin and mucous membranes). In 2004, cases of rabies transmission through solid organ transplantation were reported in the United States and Europe. ${ }^{4}$

The diagnosis of rabies is challenging because of the long incubation period (20-60 days on average, with rare reports of 5-6 days and up to 7 years) and the lack of specificity of early prodromal symptoms and neurologic symptoms, including paresthesias, pruritis and pain at the site of viral entry. ${ }^{5}$ The infection eventually evolves into a viral encephalitis (furious rabies), with classic symptoms of hydrophobia, aerophobia, hyperexcitability and autonomic dysfunction. Most patients with these symptoms die within a few days. The less common clinical presentation is the paralytic (dumb) form of rabies, which has a more protracted clinical course, with progressive paresthesias and flaccid paralysis. Rapid diagnostic tests are not available. The current standard is direct fluorescent antibody testing of fresh samples of brain tissue. Other accept- able tests are reverse-transcriptase polymerase chain reaction of brain tissue, and supportive histopathology of brain tissue for signs of leptomeningeal inflammation and characteristic intracytoplasmic inclusion bodies (Negri bodies, which are seen less commonly in human cases than in infected animals).

Cases of human rabies with overt clinical symptoms are essentially fatal. No antiviral or immunomodulating drugs have been found to be effective for treatment. ${ }^{5}$ Therefore, a preventive strategy is most appropriate. ${ }^{6}$ In developing countries, domestic and stray dogs are the main source of rabies. In I983, Latin America implemented a strategy to eliminate human rabies transmitted by dogs through the provision of free medical care to nearly I million people, vaccination of 44 million dogs, and investment in surveillance systems and education programs about the disease. The result has been a dramatic reduction in human cases there, from 355 in 1982 to 29 in $2006 .^{1}$

Table 1: Postexposure prophylaxis for people not previously vaccinated against rabies*

\begin{tabular}{|c|c|c|}
\hline Animal & $\begin{array}{l}\text { Condition of animal } \\
\text { at time of exposure }\end{array}$ & Management of exposed person \\
\hline \multirow[t]{3}{*}{ Dog, cat or ferret } & \multirow{2}{*}{$\begin{array}{l}\text { Healthyt and available } \\
\text { for } 10 \text {-day observation }\end{array}$} & 1. Local treatment of wound \\
\hline & & $\begin{array}{l}\text { 2. Administration of human rabies } \\
\text { immune globulin (locally and } \\
\text { intramuscularly) and rabies } \\
\text { vaccines at first sign of rabies in } \\
\text { animal (or immediately if bite is } \\
\text { to head or neck) }\end{array}$ \\
\hline & $\begin{array}{l}\text { Rabid or suspected of } \\
\text { being rabidף; or condition } \\
\text { unknown, animal not } \\
\text { available for } 10 \text {-day } \\
\text { observation }\end{array}$ & $\begin{array}{l}\text { 1. Local treatment of wound } \\
\text { 2. Administration of human rabies } \\
\text { immune globulin (locally and } \\
\text { intramuscularly) and rabies } \\
\text { vaccines }\end{array}$ \\
\hline \multirow{2}{*}{$\begin{array}{l}\text { Skunk, bat, } \neq \text { fox, } \\
\text { coyote, raccoon and } \\
\text { other carnivores }\end{array}$} & \multirow{2}{*}{$\begin{array}{l}\text { Regard as rabid } \emptyset \text { unless } \\
\text { geographic area is } \\
\text { known to be rabies free }\end{array}$} & 1. Local treatment of wound \\
\hline & & $\begin{array}{l}\text { 2. Administration of human rabies } \\
\text { immune globulin (locally and } \\
\text { intramuscularly) and rabies vaccine§ }\end{array}$ \\
\hline $\begin{array}{l}\text { Livestock, rodents } \\
\text { or lagomorphs } \\
\text { (hares and rabbits) }\end{array}$ & \multicolumn{2}{|c|}{$\begin{array}{l}\text { Consider individually. Consult appropriate public health and } \\
\text { Canada Food Inspection Agency officials. Bites of squirrels, } \\
\text { chipmunks, rats, mice, hamsters, gerbils, other rodents, } \\
\text { rabbits and hares may warrant postexposure prophylaxis if the } \\
\text { behaviour of the biting animal was highly unusual. }\end{array}$} \\
\hline
\end{tabular}

*Adapted from the Canadian Immunization Guide, 7 th edition, ${ }^{3}$ with the permission of the Minister of Public Works and Government Services Canada.

tIncludes animals with a history of vaccination.

¥Includes bats found in the room where a person was sleeping unattended.

SUse either type of vaccine currently available (human diploid cell vaccine or purified chick embryo cell culture vaccine).

IIf possible, the animal should be humanely killed and the brain tested for rabies as soon as possible; holding for 10-day observation is not recommended. Stop rabies vaccination if result of fluorescent antibody test of animal brain is negative. 
Table 2: Dosage of rabies vaccine

\begin{tabular}{ll}
\hline Purpose & \multicolumn{1}{c}{ Vaccine dosage } \\
\hline $\begin{array}{l}\text { Pre-exposure prophylaxis } \\
\text { and } 21\end{array}$ & \\
$\begin{array}{l}\text { Postexposure prophylaxis } \\
\begin{array}{l}\text { People previously vaccinated against } \\
\text { rabies within } 2 \text { years and who have } \\
\text { evidence of immunity* }\end{array}\end{array}$ & $\begin{array}{l}1.0 \mathrm{~mL} \text { intramuscularlyt on days } 0 \text { and } 3 ; \\
\text { no human rabies immune globulin }\end{array}$ \\
$\begin{array}{l}\text { People not previously vaccinated } \\
\text { against rabies }\end{array}$ & $\begin{array}{l}1.0 \mathrm{~mL} \text { intramuscularlyt on days } 0,3,7,7 \\
14 \text { and } 28, \text { plus human rabies immune } \\
\text { globulin }(20 \mathrm{IU} / \mathrm{kg}) \text { within } 7 \text { days of first } \\
\text { vaccine dose }\end{array}$ \\
\hline
\end{tabular}

*In the absence of documented immunity, the full schedule of postexposure prophylaxis is indicated. †Deltoid muscle or anterolateral thigh in infants.

Source: Canadian Immunization Guide, 7 th edition. ${ }^{3}$

In North America, the new challenge is rabies transmitted by wildlife, particularly bats. Most bat bites go unrecognized, and often there is a lack of history of bat exposure.

Two vaccine strategies are currently recommended: pre-exposure prophylaxis for select high-risk groups (certain laboratory personnel, veterenarians, spelunkers, people travelling to rabies-endemic countries, and animal trappers) and postexposure prophylaxis based on risk of exposure (Table I). The 2 vaccines currently licensed for use in Canada are Imovax (human diploid cell vaccine) and RabAvert (purified chick embryo cell culture vaccine) (Table 2). Both vaccines have similar immunogenicity, efficacy and safety. ${ }^{3}$ In Canada, the vaccines are recommended to be given intramuscularly; however, the World Health Organization has recommended that intradermal administration is equally acceptable.

For postexposure prophylaxis, local treatment of the wound is most important in preventing infection. This in- volves vigorous washing, preferably with soap, and flushing of the wound, followed by application of $70 \%$ ethanol or povidone-iodine solution, with delayed wound closure. Following local wound treatment, as much as possible of the full dose of human rabies immune globulin $(20 \mathrm{IU} / \mathrm{kg})$ should be administered directly into the wound. What is left in the syringe should be injected intramuscularly at a site away from the site of vaccination. The human rabies immune globulin and the rabies vaccine should be given within 7 days of each other, but not in the same syringe or at the same injection site. Postexposure prophylaxis should be given regardless of how much time has elapsed since exposure. Booster doses of the vaccine are indicated for highrisk groups when antibody titres fall below $0.5 \mathrm{IU} / \mathrm{mL}$; routine monitoring of titres every 2 years is recommended in such groups.

The Committee to Advise on Tropical Medicine and Travel has provided recommendations for the use of rabies vaccine in travellers. ${ }^{7}$ It is difficult to estimate the risk posed to travellers to rabies-endemic countries. In one study, involving I882 people who visited Thailand for 17 days on average, I3 dog bites per Iooo tourists occurred. Routine preexposure vaccination is not recommended for all Canadians travelling to high-risk areas, because of its estimated cost of $\$ 3.3$ million per adult and child saved. ${ }^{7}$ Instead, select high-risk groups should be considered for this strategy. Pre-exposure vaccination should be considered for people travelling to countries with limited access to human rabies immune globulin (China, India and most of Africa). It should also be considered for those travelling to rabies-endemic countries where postexposure prophylaxis is unavailable.

\section{Shariq Haider MD \\ Division of Infectious Diseases \\ Department of Medicine \\ McMaster University \\ Hamilton, Ont.}

This article has been peer reviewed.

Competing interests: None declared.

\section{REFERENCES}

I. Voelker R. Global effort takes aim at rabies. JAMA 2007;298:1749-50.

2. Blanton JD, Hanlon CA, Rupprecht CE. Rabies surveillance in the United States during 2006. J Am Vet Med Assoc 2007;231:540-56.

3. National Advisory Committee on Immunization. Rabies vaccine. In: Canadian immunization guide. $7^{\text {th }}$ ed. Ottawa: Public Health Agency of Canada; 2006. p. 285-97. Cat no HP40-3/2006E. Available: www .phac-aspc.gc.ca/publicat/cig-gci/index-eng.php (accessed 2008 Jan I4).

4. Plotkin SA. Rabies. Clin Infect Dis 2000;30:4-12.

5. Jackson AC, Warrell MJ, Rupprecht CE, et al. Management of rabies in humans. Clin Infect Dis 2003; 36:60-3.

6. Willoughby RE Jr, Tieves KS, Hoffman GM, et al. Survival after treatment of rabies with induction of coma. N Engl J Med 2005;352:2508-I4.

7. Committee to Advise on Tropical Medicine and Travel (CATMAT). Statement on travellers and rabies vaccine. Can Commun Dis Rep 2002;28:I-I2. 